\title{
Academic Degree Programs And Living-Learning Communities
}

Diane H. Jackman, (Email: P10DHJ1@wpo.cso.niu.edu), Northern Illinois University Margaret Myles, (Email: mmyles@niu.edu), Northern Illinois University

\begin{abstract}
Living-learning communities can be effective in enhancing academic programs at universities and the undergraduate student experience. Information on a successful program focused on teacher education will be shared.
\end{abstract}

\section{INTRODUCTION}

\& n 1994 the American College Personnel Association (ACPA) identified issues of student success explaining that the solution to enhance learning and intellectual development was to develop "educationally purposeful activities, both inside and outside the classroom" (p. 1). In 1997, the Kellogg Commission on the Future of State and Land-Grant Universities called on colleges and universities to strengthen undergraduate education. Much like the ACPA, this Commission stated that in order to be effective in doing so, a bridge must be made between students in-and-out of class educational experiences (Pike, 1997). As a result, learning communities began to develop across campuses. These learning communities are defined in a multitude of ways and implemented differently even within one institution. According to Lenning and Ebbers (1999), four basic categories of learning communities must be considered: "curricular learning communities, classroom learning communities, residential learning communities, and student-type learning communities" (p.5).

Pascarella and Terenzini (1991) suggest the effects of these communities may be indirect and "mediated by interpersonal contacts with peers and faculty and thus derive more from the socialization processes they tend to facilitate than from any of the structural characteristics of the program itself" (p. 261). This is reiterated by Golde \& Pribbenow (2000), who further comment that faculty involvement, even something as informal as dinner with students, has been found beneficial to the student participants. However, as indicated by Matthews (1994), regardless of the actual format, "in their most beneficial form, faculty carefully plan the membership, format, linkages, and programming for the learning community" (Lenning and Ebbers, p. 29, 1999).

Matthews (1994) comments on this notion stating that:

Learning communities are not merely block programming, an administrative convenience that facilitates registration and use of rooms. Rather they are conscious intellectual structures that teachers create, and students participate in, to share a high quality and enduring educational experience. . . There are as many variations on the models of learning communities as there are institutions willing to participate. All, however, strive to provide an intense and supportive environment for intellectual growth and development (p. 184).

Campus residence halls provide one locale where college experiences that lead to gains in learning and intellectual development can converge. As indicated by Pike (1997), residential learning communities were initiated in an attempt to create environments to "promote higher levels of student involvement in out-of-class activities, greater interaction between faculty and student, and a more supportive peer environment" (p. 3). Generally, students living in these types of residential learning communities, "have higher levels of academic achievement (i.e. grades), cognitive development, and persistence than do students in traditional residence halls (p. 3). 
Astin (1993) and Tinto (1998) developed theories of persistence and student success which echo the positive findings for learning communities as a whole. As explained by Lenning and Ebbers (1999): "The models suggest that learning communities should increase students' development, achievement, and persistence through encouraging the integration of social and academic lives within a college or university and its programs, and through quality interaction with peers, faculty members, and the campus environment" (p. 61-62).

More recent findings reiterate the positive effects of student participation in learning communities. For example, a comprehensive review of Lindblad in 2000 (as cited by Stassen, 2003) suggests that students in learning communities have "greater institutional commitment, greater intellectual development and opportunity to analyze and integrate ideas, greater tolerance for difference and appreciation for pluralism, and demonstrate higher persistence and academic performance as measured by college grade point average (GPA)." (p. 583).

Many studies have indicated positive results in learning from learning community involvement. "These positive student outcomes include improved student performance, persistence, and increased academic engagement, general satisfaction, and personal development." (Stassen, 2003, p. 584).

\section{NORTHERN ILLINOIS UNIVERSITY — ACADEMIC RESIDENTIAL PROGRAMS}

Every residence floor on campus promotes academic success. Academic Residential Programs go one step further, strengthening connections between students and faculty within a chosen course of study. These dynamic learning communities have some added benefits including:

- $\quad$ Formal And Informal Out Of Class Interaction With Professors In Your Academic Field.

- $\quad$ Increased Opportunity For Career Information, Internships, And Professional Networking.

- $\quad$ Access To Special Facilities And Equipment In A Supportive Learning Environment.

- $\quad$ Educational Programs That Will Enhance Your Classroom Learning.

- $\quad$ Social And Cultural Activities With Students And Faculty.

Each of the academic residential programs is unique and interesting. They are jointly sponsored by Housing and Dining and an academic unit of the University. There is at least one faculty advisor from each academic department or college affiliated with each floor.

Northern Illinois University Student Housing and Dining Services. (2001). Retrieved on February 14, 2005, from http://www.niu.edu/housing/default.shtml

\section{HISTORY OF THE TEACHER EDUCATION AND CERTIFICATION HOUSE (T.E.A.C.H. HOUSE)}

T.E.A.C.H. House is one such academic option offered at NIU in the residence hall system. In the fall of 1996, the associate provost initiated the academic certification floor. This program brings together students desiring to enter the teaching profession from four different academic colleges. Through interaction with peers and faculty this community of learners supports academic and university life, enhances and broadens understanding of the profession, and provides a diverse environment and numerous opportunities to develop leadership skills.

This first year 17 students were recruited and an Advisory Board was established with representatives from the College of Education, Health and Human Sciences, Liberal Arts and Sciences and Visual and Performing Arts. The residents were required to attend chat sessions held on the floor and the University Coordinator for Teacher Certification oversaw these efforts. The residents were also charged an additional $\$ 50.00$ fee each semester to reside on the T.E.A.C.H. floor. One half of the fee went directly back to the T.E.A.C.H. Floor to support programming and activities of the T.E.A.C.H. Floor residents. The remaining half went toward facilities in Student Housing and Dining.

Upon reviewing the effectiveness of the chat sessions, a new course was developed, IEDU 101, which all T.E.A.C.H. Floor residents were required to enroll in 1997. This was in essence a seminar with presentations by professionals in the field on current issues in education. 
In 1998, the T.E.A.C.H Floor expanded to two floors, serving 52 students. The staff experienced difficulty with enrolling all the residents in the required course. The variation of schedules was too great and prohibited one standard meeting time. In addition, the two floors were split in location ( 2 separate residence halls). This prompted a decision to return to one floor in 1999 and to only require new students to take the course designated UEDU 300.

Along with the change in designation, the course content was also reviewed and in 1999 the course focused on community building as well as enhancing the educational curriculum through presentations. With the change in focus for the class, it was decided in 2000 that all residents would be required to enroll in the course for the first semester; only new residents to the floor were required to enroll for both the first and second semester. Programming became a focus during this year as returning residents were required to plan and implement a floor activity and all residents were required to participate in at least two of the floor activities during the second semester. It was during this year, 2000, that the T.E.A.C. H. Floor was filled will all teacher certification students.

As the interest in the T.E.A.C.H. Floor grew, a decision to merge with the Honors House developed within the office of Housing and Dining in 2001. This would allow growth in both areas, but not overestimate the ability to fill 250 spots. During this year, the Honors Program and the T.E.A.C.H. program shared three floors. UEDU 300 continued to be required, however was now lead by NIU faculty, rather than the University Coordinator for Teacher Certification.

In 2002, the T.E.A.C.H. Floors and the Honors floors were separated to give T.E.A.C.H. its own two floors within the Honors House. The coordination of the floors moved from the Director of the University Office for Teacher Certification to the sponsoring colleges, Education. Health and Human Sciences, Liberal Arts and Science, Visual and Performing Arts. The College of Education took the lead on this project with the Director of Advising and Student Services taking on the coordinator position.

NIU's Student Housing and Dining continued to distribute information about this special option for students to select from when registering for on-campus housing. In addition, the Coordinator of the T.E.A.C.H. Floor recruited students at the University Open Houses and Summer Orientation Programs as space was available. As student interest increased for the T.E.A.C.H. Floor, parameters were set regarding eligibility to reside there. Any incoming freshmen who indicate a teacher certification program or incoming transfer students who indicate a teacher certification program and had a 2.5 overall GPA were eligible for the floor. Residents who wished to return to the T.E.A.C.H. Floor from a previous year were required to have earned a 2.5 cumulative GPA and declared a major in a teacher certification.

It was during this year that a formal contract was developed for residents to sign regarding the requirements to be a resident on the T.E.A.C.H. Floor. The contract included the following:

- $\quad$ Professional Lifestyle And Attitude All T.E.A.C.H. Floor residents will live in a community of learners, exemplifying the lifestyle of a future teacher. The floor objective is to provide an academic environment conducive to serious study, as well as a collaborative atmosphere for cooperative living.

- $\quad$ GPA The required GPA (Grade Point Average) for continuing students to reside on this floor is a minimum 2.50 overall. If a student does not achieve a 2.50 , supportive measures will be available to help the student raise his/her GPA. If the GPA does not rise above a 2.50 after one semester, the student may be asked to leave the floor.

- $\quad$ Professional Development The T.E.A.C.H. Floor residents will be notified of professional development opportunities available for teachers. Students will be required to attend at least 2 programs per semester.

- $\quad$ Mentoring Program All T.E.A.C.H. Floor residents will participate in a mentoring program, returning students matched to new students. Participants will be required to meet in person at least two times during the semester.

The residents were monitored for maintaining the minimum GPA, attendance at the required programs and participation in the mentoring program. Failure to meet any of these requirements put the student on floor probation. As a result of that status they were required to meet with the Coordinator to discuss their situation. This gave the 
opportunity to intervene with a student who might need assistance in getting acclimated to NIU, need academic assistance, or simply an opportunity to discuss if this is the right environment and/or major for them.

At the completion of the fall 2002, 18 of the 115 teacher certification candidates were placed on probation for low GPA. Four of the 30 students requesting to return for the 2003-2004 semester were on probation for low GPA at the end of the spring 2003 semester. Those four students appealed to return and were granted permission after consideration by the House Coordinator.

In 2002, UEDU 300 course was eliminated as a requirement based on information collected from current and past floor residents. Programming became the focus and all residents were required to attend at least two programs per semester and participate in a mentoring program (returning students with new residents).

Five floor leaders were hired to develop and implement programming initiatives with the guidance of the coordinator. This allowed for two leaders per floor and one student supervisor. This staff was compensated for their work with a single room at no charge to them. The role of the floor leader was to provide support for residents on the floors. This meant developing programs and activities that would provide professional development in the field of teaching. It required coordination with the Community Advisors, the program coordinator, and other individuals designated by the T.E.A.C.H. Floor. As the liaison for the residents to the House Coordinator, house leaders were expected to conduct themselves professionally in all dealings with residents, faculty, and staff and to support each other in their programming efforts. The house leader staff was required to spend 20 hours per month working for the TEACH Floors, to include: program planning, two hours per week designated for office hours, two hours per week designated community building hours, and to attend bi-weekly — one hour meetings with the House Coordinator.

As programming was the main focus for the floor leaders, general guidelines were established regarding their planning. All programs and their advertisement required approval by the House Coordinator at least one week in advance of the scheduled program. The program topics were scheduled on a monthly basis so that residents would know what to expect for that month and could plan accordingly. There was at least one program planned per week that was related to professional development issues. Additionally, each floor leader was responsible for maintaining an attendance record for each resident on their floor.

Technology was an added resource for residents on the T.E.A.C.H. Floors that year as well. The Office of the Provost, along with the Dean's Office in the College of Education donated computers and printers so that each floor lounge would have two computers. This gave students direct access to technology without having to leave their residence hall floor. The floor leaders became responsible for checking the computers one time per week to be sure paper/ink was stocked and computers were working. As a direct result from resident feedback, a T.E.A.C.H. floor webboard was established as an alternate means to communicate information about programs to the residents.

Even with these changes, the goals of the T.E.A.C.H. Floors remained the same:

- $\quad$ Create A Community Of Learners.

- $\quad$ Create An Environment Where Residents Explore Shared Interests.

- $\quad$ Provide Interaction With Teacher Certification Faculty.

- $\quad$ Create An Environment That Provides Learning Opportunities Outside Of The Classroom.

- $\quad$ Create An Environment Where Residents Can Explore Their Career Choice.

- $\quad$ Provide The Opportunity To Develop Mentoring Relationships.

The T.E.A.C.H. Floors became a House (5 floors) in 2003 and moved to a different residence hall. The coordination of the House remained in the College of Education, working collaboratively with the College of Liberal Arts and Sciences. During this year $3 \frac{1}{2}$ of the 5 floors were filled with students pursuing some area of teacher certification. In an effort to ensure filling the floors with interested residents, students requesting to reside in the T.E.A.C.H. House were allowed to request a roommate who was not pursing a teacher certification program. 
In addition, five faculty members were identified to act as program advisors from the Colleges of Education and Liberal Arts and Sciences. Faculty were compensated for their efforts with an administrative meal plan from Student Housing and Dining. They also received \$500 in funding from Student Housing and Dining that matched the $\$ 500$ compensation that the Colleges provided. The faculty advisors were required to present one program for the House residents each semester, serve on an advisory committee for the T.E.A.C.H. House, act as a T.E.A.C.H. House liaison to the Colleges and promote the educational community among faculty, attend events planned by the house leaders, and eat dinner once a semester with students from the T.E.A.C.H. House.

The mentoring program established in 2002 was eliminated from the contract as student involvement was minimal and student feedback found it unhelpful. However, mentoring continues to be encouraged on an informal basis by the newly named house leaders (formerly floor leaders) and Community Advisors. House Leaders were now selected, one for each floor, and worked to develop programming initiatives. A total of 36 programs were planned and executed in the 2003-2004 academic year. These programs ranged in focus from a visit with Chicago Public Schools to a panel of students currently enrolled in student teaching.

In 2003, the T.E.A.C.H. House experienced a lower return rate with the change in location. Of the 115 students from 2002-2003, only 30 opted to move to the new residence hall with the program. However, the House did recruit new freshman and transfer students to fill the 250 spaces with 182 of them being teacher certification candidates.

At the end of the fall 2003 semester, 39 of the 182 teacher education students were placed on floor probation as a result of not meeting the required 2.5 cumulative GPA. At the conclusion of the spring 2004 semester, 13 of the 60 teacher education students, requesting to return to the T.E.A.C.H. House for the 2004-2005 year, did not meet the required 2.5 cumulative GPA. These 13 residents appealed their eligibility to return to the T.E.A.C. H. House. After discussion of academic resources and the issues that prevented their attainment of a 2.5 GPA, it was decided by the House Coordinator to allow their return.

The current year, 2004-2005, is the first experience with some stability and consistency for the program. The Coordinator and the faculty advisors remained the same as did the House requirements and the role of the house leaders. At this time, the T.E.A.C.H. House is filled with 216 of the 250 residents being teacher certification majors, 60 of them being returning students from the previous year. Educational programming continues to be the focus of the T.E.A.C.H. House. At the current time, the House Leaders have planned and executed 26 programs. Some examples of this year's programs include: Field Trip to the Pilsen Community to visit a predominately Spanish speaking elementary school and the Mexican Fine Arts Museum.; Healthy at Every Size: Encouraging Students to Focus on Health not Weight; Clinical Expectations; and Dinner with the Faculty Advisors.

At the end of the fall 2004 semester, 48 of the 216 teacher education students were placed on floor probation as a result of not meeting the required 2.5 cumulative GPA. The House Coordinator is currently meeting with those students to provide information regarding academic resources, as well as identify academic goals and ways to achieve them.

The T.E.A.C.H. House residents have decided to make investing in their surroundings a priority. Funds from Housing and Dining, as well as funds from the T.E.A.C.H. House budget were allocated for murals to be painted in the entry way and the stairwell of the T.E.A.C.H. House. In addition, T.E.A.C.H. House funds were approved for the purchase of inspirational posters to be hung throughout each of the five residence hall floors. The residents agreed that making the environment friendlier, appealing, and teacher focused was another way to encourage interaction among residents and their commitment to our goals in the T.E.A.C.H. House.

\section{CONCLUSION}

The current research leads us to the conclusion that universities must begin to think 'outside the box' to make notable improvements in the learning and development of students. Participants of living-learning communities show "significantly larger gains in intellectual orientation than do students in traditional curricular programs" 
(Pascarella \& Terenzini, 1991). It no longer is enough to teach in the traditional classroom, and that in fact is becoming archaic. Living Learning Communities are one example of how higher education can move toward assisting students on their path to not only academic achievement, but attainment of life goals.

\section{REFERENCES}

1. American College Personnel Association. (1994). The student learning imperative: Implications for student affairs. Washington, DC: Author.

2. Golde, C. M. \& Pribbenow, D. A. (2000). Understanding faculty involvement in residential learning communities. Journal of College Student Development, 41(1).

3. Kellogg Commission of the Future of State and Land-Grant Universities. (1997). Returning to our root: The student experience. Washington, DC: National Association of State Universities and Land-Grant Colleges.

4. Lenning, O. T. \& Ebbers, L. H. (1999). The powerful potential of learning communities: Improving education for the future. The George Washington University, Graduate School of Education and Human Development. (ERIC Document Reproduction Service No. ED428606)

5. Matthews, R. S. (1994). Enriching teaching and learning through learning communities. In T. O’Banion (ed.), Teaching and learning in the community college (pp. 179-200). Washington, DC: American Association of Community Colleges.

6. Pascarella, E. T. \& Terenzini, P. T. (1991). How college effects students. San Francisco: Jossey-Bass.

7. Pike, G. R. (1997). The effects of residential learning communities on students' educational experiences and learning outcomes during the first year of college. Albuquerque, NM: Association for the Study of Higher Education. (ERIC Document Reproduction Service No. ED415828)

8. Stassen, J. L. (2003). Student outcomes: The impact of varying living-learning community models. Research in Higher Education, 44(5). 